\title{
Adölesanlarda Porsiyon Seçimi ile Beden Kütle İndeksi Arasındaki İlişkinin İncelenmesi
}

\author{
Investigating the Association between Portion Choices and Body Mass Index in Adolescents
}

\author{
Hanım Ecem Diktaş ${ }^{1,2}$, Hilal Hızlı², Muazzez Garipağaoğlu ${ }^{2,3}$
}

Geliş tarihi/Received: 10.09.2018 • Kabul tarihi/Accepted: 18.10.2019

\section{ÖZET}

Amaç: Besinlerin artan porsiyon büyüklüklerinin, vücut ağırlığını, dolayısıyla sağlığı̈önemli derecede etkilediği bilinmektedir. Bu nedenle bu çalışma 14-18 yaş grubu adölesanlarda porsiyon seçimi ile beden kütle indeksi (BKİ) arasındaki ilişkinin incelenmesi amacıyla yapılmıştır.

Bireyler ve Yöntem: Randomize, kesitsel bir araştırma olan çalışma, İstanbul ilinde lise eğitimi gören (özel ve devlet lisesi) 14-18 yaşları arasındaki 257’si kız 253’ü erkek, toplam 510 öğrencinin katılımıyla gerçekleştirilmiştir. Antropometrik ölçümler bir diyetisyen tarafindan alınmış, günlük beslenme alışkanlıkları, porsiyon seçimleri ve ailelerin sosyo-ekonomik düzeylerine ilişkin veriler anket formu ile toplanmıştır. Porsiyon seçimleri, öğle yemeği öncesinde (açlık durumunda) ve öğle yemeği sonrasında (tokluk durumunda) olmak üzere 2 kez incelenmistir.

Bulgular: Beden kütle indeksine göre öğrencilerin \%33.6’sı kilolu ve obez, \%2.2’si zaylf, \%64.3’ü normal bulunmuştur. Yemek porsiyonlarına daha az dikkat ettiğini belirten öğrencilerin, daha büyük porsiyonu seçtikleri görülmüştür ( $p<0.05)$. Erkek öğrencilerin kızlara göre daha büyük porsiyonları seçtikleri saptanmıştır ( $p<0.001$ ). Öğrencilerin günlük aldıkları enerji ile seçtikleri porsiyonun büyüklüğü arasında pozitif bir ilişkinin olduğu gözlenmiştir ( $r=0.355, p<0.001)$. Küçük, orta ve büyük porsiyon seçen öğrencilerin günlük enerji alımları sırasıyla $1361 \mathrm{kkal}, 1717$ kkal, 2190 kkal bulunmuştur (p<0.001). BKİ ve porsiyon seçimi konusunda istatistiksel olarak anlamlı bir ilişki bulunamamıştır ( $r=-0.015, p>0.05)$. Öğrencilerin tokluk durumunda daha küçük porsiyonları tercih ettikleri ( $p<0.001)$, okul tipinin porsiyon seçimini etkilemediği görülmüştür.

Sonuç: Öğrencilerin porsiyon seçimlerinin günlük enerji ve makro besin ögesi alımına paralel olduğu ancak bu seçimlerin beden kütle indekslerinden bağımsız olduğu gözlenmiştir.

Anahtar kelimeler: Adölesan, BKİ, porsiyon seçimi, enerji alımı

\section{ABSTRACT}

Aim: It is known that the increased portion size of foods effects body weight, thereby significantly influences individuals' health. This study was planned to investigate the association between portion choice and body mass index in a group of adolescents aged between 14 to 18 years.

Subjects and Method: This randomized cross-sectional study was carried out with 510 students (257 females, 253 males) aged between 14 and 18 who were students at one private and one public school. Anthropometric measurements of the students

1. İletişim/Correspondence: The Pennsylvania State University, Department of Nutritional Sciences, Laboratory for the Study of Human Ingestive Behavior, University Park PA, USA • E-posta: hanimecem@hotmail.com

(D) https://orcid.org/0000-0002-4603-3719
2. İstanbul Medipol Üniversitesi, Sağlık Bilimleri Fakültesi, Beslenme ve Diyetetik Bölümü, İstanbul, Türkiye (ㄱ) https://orcid.org/0000-0002-3951-5023

3. Fenerbahçe Üniversitesi, Sağlık Bilimleri Fakültesi, Beslenme ve Diyetetik Bölümü, İstanbul, Türkiye

(D) https://orcid.org/0000-0003-2172-1467 
were assessed by a dietitian. Surveys about demographic information of families, eating patterns, and portion choices of children (in the presence or absence of hunger) were conducted. A portion survey was conducted two times, before (in the presence of hunger) and after the students' lunchtime (in the absence of hunger).

Results: According to the body mass index (BMI), 33.6\% of the students were overweight and obese, $2.2 \%$ were underweight, and $64.3 \%$ were normal weight. The students who were unaware of the size of their regular portions chose the bigger portion $(\mathrm{p}<0.05)$. The male students chose bigger portions than female students $(\mathrm{p}<0.001)$. There was a positive association between daily energy intakes and portion size choices $(r=0.355, p<0.001)$. The students' dietary recall data indicated that daily average energy intake increased as chosen portion size increases $(p<0.001)$. The energy intake of the students who chose small, medium, and large portion sizes were $1361 \mathrm{kcal}, 1717 \mathrm{kcal}$, and $2190 \mathrm{kcal}$, respectively. There was no significant correlation between BMI and portion selection ( $\mathrm{r}=-0.015, \mathrm{p}>0.05)$. Additionally, in the absence of hunger the students chose smaller portions $(\mathrm{p}<0.001)$. There was no association between the students' portion choices and school type.

Conclusion: Although students' portion choices and daily energy-macronutrient intakes were highly correlated, the portion choices were independent by students’ BMI.

Keywords: Adolescent, BMI, portion choice, energy intake

\section{GİRIŞ}

Porsiyon büyüklüğü etkisi (portion size effect) literatürde sunulan besin miktarının artması ile birlikte daha fazla besin tüketiminin gözlenmesi olarak tanımlanmaktadır (1). Bu etki ana öğünlerde ve atıştırmalıklarda, yaş grubu farketmeksizin güçlü ve tutarlı olarak gözlenmiştir (2). Bununla birlikte, besinlerin artan porsiyon büyüklüklerinin, vücut ağırlığını, dolayısıyla sağlığı önemli derecede etkilediği bilinmektedir. $\mathrm{Bu}$ nedenle son ylllarda, birçok ülkede ideal porsiyon büyüklüklerine ilişkin çalışmalar yapılmakta, yaşa ve cinsiyete özel tüketilmesi gereken besinlerin miktarları konusunda toplumun bilinçlendirilmesi hedeflenmektedir $(3,4)$.

Adölesan dönemi, büyüme ve gelişmenin hızlı olduğu, çocukluktan erişkinliğe geçişi kapsayan önemli bir dönemdir. $\mathrm{Bu}$ dönemdeki fiziksel değişiklikler, besin gereksinimlerini etkilemektedir. Adölesanlarda başta enerji ve protein olmak üzere vitamin ve mineral gereksinimlerinin önemli ölçüde arttığı, yeme alışkanlıkları ve besin seçimlerinde belirgin değişikliklerin olduğu bilinmektedir (5). $\mathrm{Bu}$ değişikliklerden biri de adölesanların porsiyon seçimleridir. Popkin ve arkadaşları (6) tarafindan, porsiyon seçimleri üzerine yapılan 30 yll izlemli bir kohort çalışmada, adölesanların, özellikle son yıllarda oldukça büyük porsiyonlar tükettikleri ortaya konmuştur.

Yürütülen gözlemsel ve deneysel araştırmalarda porsiyon büyüklüğü etkisinin vücut ağırlığı ile ilişkisi test edilmiş, vücut ağırlığı yüksek olan adölesanların büyük porsiyonlar tüketmeye daha yatkın oldukları ortaya konmuştur. İngiltere'de yürütülen Ulusal Beslenme ve Diyet Araştırmaları Anketi'nin (UK National Diet and Nutritional Survey [NDNS]) verileri beden kütle indeksi (BKI) yüksek olan adölesanların özellikle yüksek enerjili besinleri daha büyük porsiyonlarda tükettiklerini belirtmektedir (7). Amerika'da yapılan bir diğer çalışmada ise, çocukların ana öğünleri beş gün boyunca büyük porsiyonlarla servis edilmiş, vücut ağırlığı yüksek olan çocukların büyük porsiyonlarla tüketimini arttırmaya daha yatkın oldukları bildirilmiştir (8).

Yapılan literatür taramasında ülkemizde BKİ ile porsiyon seçimi arasındaki ilişkiyi inceleyen bir çalışmaya rastlanmamıştır. Bu nedenle bu çalışma, 14-18 yaş aralığında olan bir grup lise öğrencisinin porsiyon seçimlerinin değerlendirilmesi ve porsiyon seçimlerine neden olabilecek etmenlerin belirlenmesi amacıyla planlanıp yürütülmüştür. 


\section{BİREYLER VE YÖNTEM}

\section{Araştırmanın Yeri, Zamanı ve Örneklem Seçimi}

Çalışma, 30 Mart-30 Mayıs 2016 tarihleri arasında, İstanbul İli Başakşehir İlçesi'nde bir özel ve bir devlet lisesinde öğrenim gören, 14-18 yaş aralığındaki 257 kız ve 253 erkek olmak üzere toplam 510 öğrenci ile yapılmıştır. Kesitsel ve tanımlayıcı tipteki bu çalışma için İstanbul Medipol Üniversitesi Girişimsel Olmayan Klinik Araştırmalar Etik Kurulu'ndan 10840098604.01.01-E.4610 sayllı ve 24/03/2016 tarihli "Etik Kurul Onayı” alınmıştır.

İstanbul İl Milli Eğitim Müdürlüğü’nden araştırmanın Avrupa Yakası'ndaki liselerde yürütülmesi için izin alınmış ve randomizasyonla Avrupa yakasındaki ilçeler arasından Başakşehir çalışma bölgesi olarak belirlenmiştir. Başakşehir İlçesi Milli Eğitim Müdürlüğü’ne bağlı liseler, mevcut öğrenci sayısı, aktivite alanları, okul bahçeleri, yemekhane hizmetleri, sosyo-ekonomik düzey gibi değişkenler açısından değerlendirilmiş ve randomizasyonla belirlenen biri özel ve biri devlet lisesi olmak üzere iki ayrı lisede çalışma yürütülmüştür. Uygun yaş aralığında bulunmayan, BKI'si $40 \mathrm{~kg} / \mathrm{m}^{2}$ 'nin üzerinde olan 10 öğrencinin verileri analizlere dahil edilmemiştir. Örneklem büyüklüğü G-Power 3.1 programı ile, her bir grup için (özel ve devlet lisesi) 105 katılımcı, toplam 210 katılımcı olarak belirlenmiştir (9).

\section{Verilerin Toplanması}

Öğrencilere ilişkin sosyo-demografik bilgiler ve beslenme alışkanlığı bir anket formu ile elde edilmiştir. Anket formu, yüz yüze görüşme yöntemiyle araştırmacı tarafından uygulanmıştır. Öğrencilerin boy uzunlukları, vücut ağırlıkları ölçülmüş, BKI hesaplanmış ve anket formuna kaydedilmiştir. Boy uzunluğu, ayakkabısız ve ayaklar birleşik ve Frankfurt düzlemde (göz ve kulak kepçesi üstü aynı hizada ve baş ile boyun arasındaki açı 90 derece) duvara sabitlenmiş esnemeyen bir mezura ile ölçülmüştür. Vücut ağırlığı ise ayakkabısız ve en hafif giysilerle, hassas bir terazi ile ölçülmüştür (10).
Porsiyon büyüklüğünün belirlenmesinde öğrencilere, üç çeşit yemek ve bir çeşit içecekten oluşan üç farklı porsiyonda menü sunulmuş, sunulan porsiyonlar Resim 1'de gösterilmiştir. Yemekler, benzer konuda yapılmış çalışmalar örnek alınarak, porsiyon ölçüsü anlaşılabilir ve öğrenciler tarafından da sevilerek tüketilebilecek yiyecekler arasından seçilmiştir $(11,12)$. Menü oluşumunda, Türkiye Beslenme Rehberi modeli olan sağlıklı beslenme tabağı ve piramidi (13) ve Amerika'daki örnek tabak modeli (14) esas alınmıştır. Porsiyonlardaki her besinin miktarı önceden belirlenmiş ve Çelik Mutfak Tartısı (Optiss) ile ölçülerek tabaklara yerleştirilmiştir. Porsiyonların sunumu için $27 \mathrm{~cm}$ çapında beyaz desensiz bir tabak, içecekler için $300 \mathrm{~mL}$ hacminde cam bir bardak kullanılmıştır. Menü görselleri aydınlık bir ortamda dijital bir fotoğraf makinesi ile resimlenmiş, renkli olarak anketlere yerleştirilmiştir. Menü görselleri aynı zamanda yaş grubunun özellikleri göz önüne alınarak $40 \times 40 \mathrm{~cm}$ yiyecek, $20 \times 30 \mathrm{~cm}$ içecek olacak şekilde kalın malzemeye pankart/görsel şeklinde basilıp porsiyon anketi sırasında öğrencilere gösterilmiştir. Görsellerin amacı öğrencilerin porsiyonları daha ayrıntılı görmelerini sağlamaktır.

Açlık ve tokluk durumunun porsiyon seçimine etkisini belirlemek amacıyla porsiyon görseli, öğle yemeğinden hemen önce ve yemek sonrası ilk 45 dakika içerisinde olmak üzere 2 kez uygulanmıştır. Öğrencilere görsellerin tekrar ediliş nedeni porsiyon seçimlerini etkilememek amacıyla açıklanmamıştır.

Öğrencilerin günlük ortalama enerji ve besin ögesi alımını saptamak amacıyla 24 saatlik geriye dönük besin tüketim kaydı alınmıştır. Bunun için katılımcıların son 24 saatlik süre içerisinde tükettikleri tüm yiyecekler, içecekler ve öğün düzenleri ayrıntılı bir şekilde sorgulanarak kaydedilmiştir. Tüketilen besinlerin tür ve miktarlarının doğru hatırlanabilmesi için, besin replikaları, kaşık ölçüleri (silme, tepeleme), ölçü kapları ve miktarları (su bardağı, çay bardağı, servis kaşığı, yemek kaşığı, tatlı kaşığı, çay kaşığı, küçük, orta, büyük vb.) kullanılmıştır. 


\begin{tabular}{|c|c|}
\hline \multirow[t]{4}{*}{ Porsiyon } & İçerik \\
\hline & $\begin{array}{l}\text { Küçük boy (1/2 porsiyon) } \\
50 \text { g sade spagetti makarna } \\
30 \text { g mevsim salata } \\
45 \mathrm{~g} \text { (1.5 adet) 1zgara köfte } \\
100 \mathrm{~mL} \text { ayran } \\
\text { Enerji= } 234 \mathrm{kkal}\end{array}$ \\
\hline & $\begin{array}{l}\text { Orta boy (1 porsiyon) } \\
100 \text { g sade spagetti makarna } \\
60 \text { g mevsim salata } \\
90 \text { g ( } 3 \text { adet) lzgara köfte } \\
200 \text { mL ayran } \\
\text { Enerji= } 468 \text { kkal }\end{array}$ \\
\hline & $\begin{array}{l}\text { Büyük boy (1+1/2 porsiyon) } \\
150 \text { g sade spagetti makarna } \\
90 \mathrm{~g} \text { mevsim salata } \\
135 \mathrm{~g} \text { (4.5 adet) lzgara köfte } \\
300 \mathrm{ml} \text { ayran } \\
\text { Enerji= } 702 \mathrm{kkal}\end{array}$ \\
\hline
\end{tabular}

Resim 1. Menülerin porsiyon büyüklüğü ve içeriği

\section{Verilerin Değerlendirilmesi}

Öğrencilerin BKİleri vücut ağırlığının, boy uzunluğunun metre karesine bölünerek (kg/ $\mathrm{m}^{2}$ ) hesaplanmıştır. Hesaplanan BKI’ler Dünya Sağlık Örgütü tarafından geliştirilmiş persentil değerleri/eğrilerinde yaşa göre yerine konularak değerlendirilmiştir (15). Hesaplanan persentil değerleri Amerika Birleşik Devletleri Hastalık Kontrol ve Korunma Merkezleri (Centers for Disease Control and Prevention [CDC]) verilerine göre sinıflandırılmış, $<5$. persentil çok zaylf, 5-15. persentil zayıf, 15.-85. persentil normal, 85.-95. persentil hafif şişman ve $>$ 5. persentil obez olarak kabul edilmiştir (16). Zayıf öğrencilerin istatistiksel test için istenenden az sayıda bulunması nedeniyle, bu grup normal BKİ sınıfina dahil edilerek analiz edilmiştir.

Günlük enerji ve besin ögeleri alım miktarları, Bilgisayar Ortamında Besin Analiz Programı (BEBİs) kullanılarak belirlenmiştir (17). Elde edilen değerler, Türkiye Beslenme Rehberi'nde belirtilen önerilerle karşılaştırılmıştır (13). Yeterlilik $\pm \% 33$ sınır kabul edilerek, önerilerin \%67-133 arası tüketimler yeterli, önerilerin \%67’nin altındaki tüketimler yetersiz, \%133’ün üzeri ise fazla tüketim olarak kabul edilmiştir (18). 


\section{Verilerin İstatistiksel Değerlendirmesi}

Araştırma sonucunda elde edilen veriler, Windows ortamında SPSS 18.0 istatistiksel paket programı ile değerlendirilmiştir. Verilerin normal dağılım gösterip göstermediğine Kolmogrov-Smirnov ve Shapiro-Wilk testleriyle bakılmıştır. Nitel değişkenler arasındaki ilişkinin belirlenmesi için "Ki-kare Testi”, nicel değişkenler arasındaki ilişkinin belirlenmesinde de “İki Yönlü Kolerasyon Testi (Pearson)” uygulanmıştır. Parametrelerin gruplar arası karşılaştırılmasında "Bağımsız örnekler (Independent Samples) t-testi", normal dağılan parametrelerde üç ve üzeri grupların karşılaştırılmasında "Tek yönlü varyans analizi (One-way Anova)” kullanılmıştır. Parametreler arası ilişkilerin değerlendirilmesinde de Pearson ve Spearman korelasyon analizi kullanılmıştır. Tüm istatistiksel testlerde güven aralığı \%95, p değeri $<0.05$ olarak kabul edilmiştir.

\section{BULGULAR}

Öğrencilerin demografik özellikleri Tablo 1'de gösterilmiştir. Tüm grupta kız ve erkek öğrencilerin benzer dağıldığı, devlet okulunda kız öğrencilerin ağırlıklı (\%57.6) olduğu görülmüştür $(\mathrm{p}<0.05)$. Devlet okulundaki öğrencilerin yaş grupları birbirine benzer (15-16 yaş arası \%52.2, 17-18 yaş arası \%47.8) iken, özel okulda 17-18 yaş grubunda anlamlı olarak daha fazla (\%61.2) öğrenci bulunduğu gözlenmiştir $(p<0.05)$. Özel lisedeki kız ve erkek öğrencilerin boy uzunluğu, vücut ağırlığı ortalamalarının devlet lisesindekilerden anlamlı derecede yüksek olduğu görülmüştür $(p<0.05)$. Öğrencilerin okullara göre BKİ sınıfı dağılımlarının benzer olduğu saptanmıştır ( $\mathrm{p}>0.05)$.

Porsiyon seçiminin farklı değişkenlere göre dağılımı Tablo 2'de gösterilmiştir. Buna göre, erkek öğrenciler genellikle porsiyon seçiminde büyük porsiyonu tercih ederken, kız öğrenciler genelde orta porsiyonu tercih etmişlerdir. Erkek öğrenciler büyük porsiyonu kız öğrencilerden neredeyse üç kat daha fazla tercih etmiştir. Öğrencilerin cinsiyete göre porsiyon seçimleri arasında istatistiksel olarak anlamlı farklılık görülmüştür $(p<0.001)$. Öğrencilerin okul tipleri ve porsiyon seçimleri incelendiğinde, iki okul tipinde de porsiyon seçimlerinin benzer dağıldığı görülmüştür (p>0.05). Tüm öğrencilerin ağırlıklı olarak orta (\%46.1) ve büyük (\%45.1) porsiyonu tercih ettikleri gözlenmiştir.

Porsiyon seçimleri öğrencilerin hem BKİ sınıflarına hem de BKİ ortalamalarına göre ayrı ayrı klyaslanmıştır. Buna göre öğrencilerin porsiyon seçimleri ve BKİ sınıfları ya da BKİ ortalamaları arasında istatistiksel olarak anlamlı farklılık bulunamamıştır ( $\mathrm{p}>0.05)$.

Öğrencilerin porsiyon seçiminin yaş ortalamasına göre dağılımı analiz edilmiş, özel okuldaki öğrencilerin porsiyon seçimlerine göre yaş dağılımında anlamlı farklılık gözlenmiştir. Buna göre özellikle orta porsiyonu seçen öğrencilerin küçük porsiyonu seçenlere kıyasla anlamlı olarak daha yüksek yaş

Tablo 1. Öğrencilerin demografik özellikleri

\begin{tabular}{|c|c|c|c|c|c|c|c|}
\hline \multirow{2}{*}{ Özellik } & \multicolumn{2}{|c|}{ Devlet $(n=268)$} & \multicolumn{2}{|c|}{ Özel (n=242) } & \multicolumn{2}{|c|}{ Toplam $(n=510)$} & \multirow{2}{*}{ p } \\
\hline & Erkek & Kız & Erkek & Kız & Erkek & Kız & \\
\hline Öğrenci dağılımı (S) & 120 & 148 & 133 & 109 & 253 & 257 & \multirow{3}{*}{${ }^{\mathrm{a}} 0.022$} \\
\hline \multirow[t]{2}{*}{ Öğrenci dağılımı (\%) } & 44.8 & 55.2 & 55.0 & 45.0 & 49.6 & 50.4 & \\
\hline & $\overline{\mathrm{X}} \pm \mathrm{SS}$ & $\overline{\mathrm{X}} \pm \mathbf{S S}$ & $\overline{\mathrm{X}} \pm \mathbf{S S}$ & $\overline{\mathrm{X}} \pm \mathbf{S S}$ & $\overline{\mathrm{X}} \pm \mathbf{S S}$ & $\overline{\mathrm{X}} \pm \mathbf{S S}$ & \\
\hline Yaş (yıl) & $16.2 \pm 1.1$ & $16.4 \pm 1.1$ & $16.3 \pm 1.1$ & $16.2 \pm 1.1$ & $16.3 \pm 1.1$ & $16.3 \pm 1.1$ & b0.505 \\
\hline Boy uzunluğu (cm) & $172.9 \pm 7.7$ & $160.1 \pm 5.5$ & $175.5 \pm 7.2$ & $162.1 \pm 5.4$ & $174.3 \pm 7.6$ & $161.0 \pm 5.5$ & ${ }^{\mathrm{b}} 0.000$ \\
\hline Vücut ağırlığı (kg) & $67.1 \pm 12.4$ & $58.3 \pm 10.1$ & $74.7 \pm 14.2$ & $59.8 \pm 10.4$ & $71.1 \pm 13.9$ & $58.9 \pm 10.2$ & ${ }^{\mathrm{b}} 0.000$ \\
\hline BKİ $\left(\mathrm{kg} / \mathrm{m}^{2}\right)$ & $22.6 \pm 3.8$ & $22.8 \pm 3.7$ & $24.2 \pm 4.2$ & $22.7 \pm 3.7$ & $23.4 \pm 4.1$ & $22.8 \pm 3.7$ & ${ }^{\mathrm{b}} 0.058$ \\
\hline
\end{tabular}

aki-kare, ${ }^{b}$ Bağtmsiz gruplarda t testi, ${ }^{*} p<0.05$

BKİ: Beden kütle indeksi $\overline{\mathrm{X}}$ : Ortalama SS: Standart sapma 


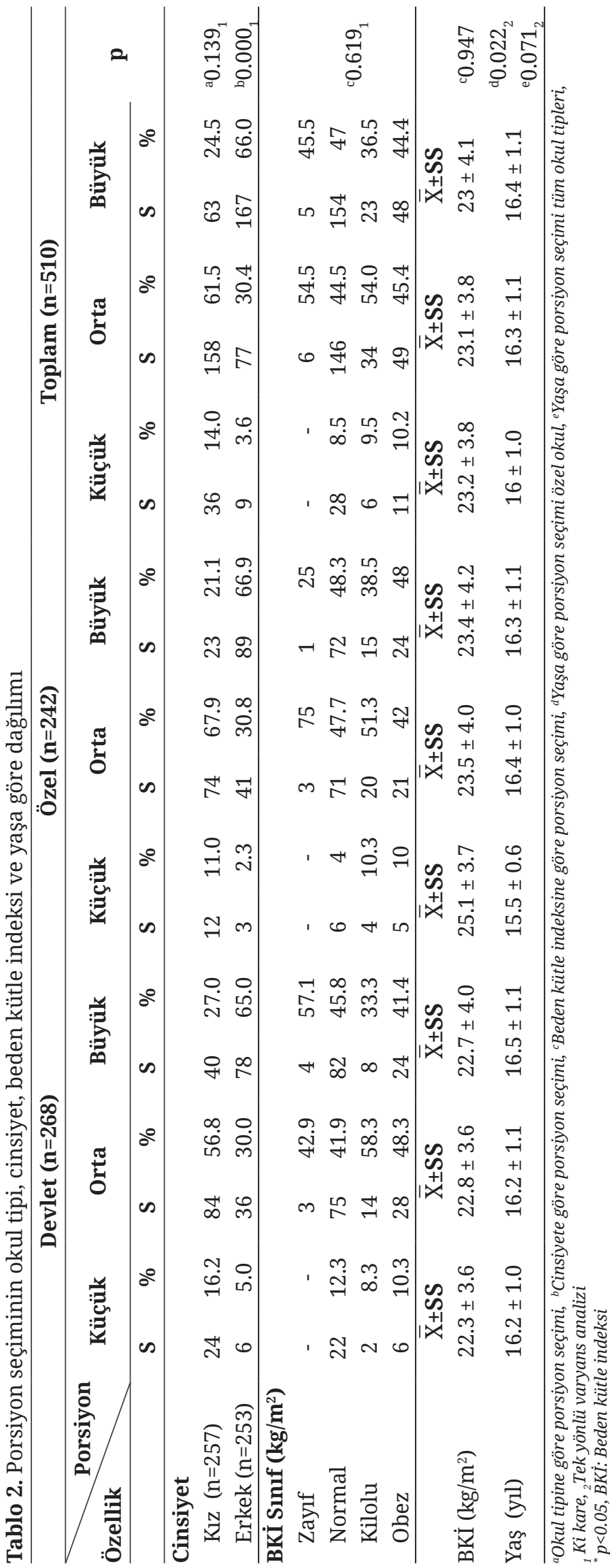

ortalamasına sahip oldugu gözlenmiştir. Analizlere iki okul tipi de dahil edildiğinde benzer farklılık görülmüş ancak bu farklılık istatistiksel olarak anlamlı bulunamamıştır ( $p>0.05)$.

Öğrencilerin besin tüketim kayıtlarından alınan sonuçlara göre, günlük enerji ve makro besin ögeleri alımları ile porsiyon seçimleri incelenmiştir (Tablo 3). Her iki okulda da gün içinde daha fazla enerji alan çocukların daha büyük porsiyonlar seçme eğiliminde oldukları gözlenmiştir $(p<0.001)$. Bununla birlikte büyük porsiyonu seçen öğrencilerin günlük makro besin ögeleri alımlarının da anlamlı derecede yüksek olduğu görülmüştür $(\mathrm{p}<0.001)$.

Öğrencilerin açlık ve tokluk durumunda büyük porsiyonu seçme dağılımı Şekil 1'de gösterilmiştir. Porsiyon seçimleri değerlendirildiğinde açlıkta öğrencilerin büyük çoğunluğu orta ve büyük porsiyonları tercih ederken, toklukta küçük porsiyonları seçtikleri saptanmıştır $(\mathrm{p}<0.001)$. Tokluk durumunda devlet okulundaki öğrenciler, özel okuldaki öğrencilere göre anlamlı oranda daha büyük porsiyonlar seçmişlerdir $(\mathrm{p}<0.001)$.

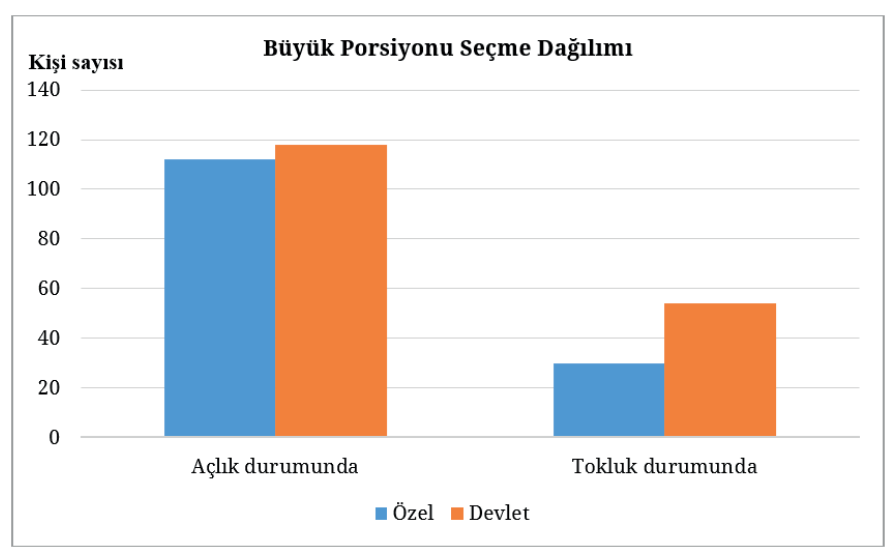

Şekil 1. Açlık ve tokluk durumunda büyük porsiyonu seçme dağılımı

Porsiyon seçimi ile ilişkili bazı parametrelerin korelasyon analizi Tablo 4'te gösterilmiştir. Yaş $(\mathrm{r}=0.095, \mathrm{p}<0.05)$, boy uzunluğu $(\mathrm{r}=0.356, \mathrm{p}<0.001)$ ve vücut ağırlığı $(r=0.177, \mathrm{p}<0.001)$ ile porsiyon seçimi arasında pozitif yönde anlamlı bir ilişki gözlenmiştir. Boy uzunluğu ve vücut ağırlığı değişkenlerinde bu ilişkinin daha güçlü olduğu saptanmıştır. 
Tablo 3. Porsiyon seçimlerine göre öğrencilerin günlük ortalama enerji ve makro besin ögeleri alımları

\begin{tabular}{|c|c|c|c|c|}
\hline & Devlet $(n=268)$ & Özel (n=242) & Toplam $(n=510)$ & \\
\hline Porsiyon & $\begin{array}{c}\text { Enerji (kkal/gün) } \\
\overline{\mathrm{X}}_{ \pm S S}\end{array}$ & $\begin{array}{c}\text { Enerji (kkal/gün) } \\
\overline{\mathrm{X}}_{ \pm S S}\end{array}$ & $\begin{array}{c}\text { Enerji (kkal/gün) } \\
\overline{\mathrm{X}}_{ \pm S S}\end{array}$ & $\mathbf{p}$ \\
\hline Küçük & $1333.8 \pm 554.3$ & $1414.5 \pm 470.5$ & $1360.7 \pm 523.8$ & \\
\hline Orta & $1920.8 \pm 707.8$ & $1504.1 \pm 472.0$ & $1716.8 \pm 637.8$ & $0.000^{*}$ \\
\hline \multirow[t]{2}{*}{$\underline{\text { Büyük }}$} & $2028.1 \pm 884.2$ & $2058.6 \pm 677.4$ & $2189.5 \pm 860.1$ & \\
\hline & $\begin{array}{c}\text { Karbonhidrat (g/gün) } \\
\overline{\mathrm{X}}_{ \pm \mathrm{SS}}\end{array}$ & $\begin{array}{c}\text { Karbonhidrat (g/gün) } \\
\overline{\mathrm{X}}_{ \pm S S}\end{array}$ & $\begin{array}{c}\text { Karbonhidrat (g/gün) } \\
\overline{\mathrm{X}}_{ \pm S S} \\
\end{array}$ & \\
\hline Küçük & $140.2 \pm 61.5$ & $138.8 \pm 64.8$ & $139.7 \pm 61.9$ & \\
\hline Orta & $211.6 \pm 83.7$ & $153.8 \pm 59.5$ & $183.3 \pm 78.3$ & $0.000^{*}$ \\
\hline \multirow[t]{2}{*}{ Büyük } & $250 \pm 127.7$ & $203.9 \pm 91.3$ & $227.5 \pm 113.6$ & \\
\hline & $\begin{array}{c}\text { Protein (g/gün) } \\
\overline{\mathrm{X}}_{ \pm \mathrm{SS}}\end{array}$ & $\begin{array}{c}\text { Protein (g/gün) } \\
\overline{\mathrm{X}}_{ \pm} \mathrm{SS}\end{array}$ & $\begin{array}{c}\text { Protein (g/gün) } \\
\overline{\mathrm{X}}_{ \pm} \mathrm{SS}\end{array}$ & \\
\hline Küçük & $55.1 \pm 29.6$ & $65 \pm 33.6$ & $58.4 \pm 31.0$ & \\
\hline Orta & $67.7 \pm 31.1$ & $61.6 \pm 26.7$ & $64.8 \pm 29.1$ & $0.000^{*}$ \\
\hline \multirow[t]{2}{*}{ Büyük } & $82.9 \pm 35.9$ & $89.5 \pm 39.0$ & $86.1 \pm 37.5$ & \\
\hline & $\begin{array}{c}\text { Yağ (g/gün) } \\
\bar{X}_{ \pm S S}\end{array}$ & $\begin{array}{c}\text { Yağ (g/gün) } \\
\bar{X}_{ \pm S S}\end{array}$ & $\begin{array}{c}\text { Yağ (g/gün) } \\
\bar{X}_{ \pm S S}\end{array}$ & \\
\hline Küçük & $59.7 \pm 26.0$ & $64.7 \pm 25.9$ & $61.4 \pm 25.8$ & \\
\hline Orta & $86.3 \pm 44.1$ & $70.1 \pm 28.6$ & $78.4 \pm 38.1$ & $0.000^{*}$ \\
\hline Büyük & $103.2 \pm 51.4$ & $96.0 \pm 40.2$ & $99.7 \pm 46.3$ & \\
\hline
\end{tabular}

Tek yönlü varyans analizi

" $p<0.001$

Günlük enerji $(\mathrm{r}=0.355, \quad \mathrm{p}<0.001)$, karbonhidrat $(\mathrm{r}=0.285, \mathrm{p}<0.001)$, protein $(\mathrm{r}=0.308, \mathrm{p}<0.001)$ ve yağ alımı $(r=0.297, p<0.001)$ ile porsiyon seçimi arasında pozitif yönde bir ilişki gözlenmiş, enerji alımı ve tokluk durumunda porsiyon seçimi değişkenlerinde bu ilişki daha güçlü bulunmuştur.

\section{TARTIŞMA}

Adölesan dönemi, bebeklikten sonra büyüme ve gelişmenin en hızlı olduğu, çocukluktan erişkinliğe geçiş dönemidir. Bu dönemdeki fiziksel değişiklikler, bedenin besin gereksinimlerini etkilemektedir. Adölesanlarda enerji ve besin ögeleri gereksinimleriyle birlikte, iştahın da arttığı bilinmektedir (19). Diğer çocukluk dönemleriyle karşılaştırıldığında, adölesanların besinleri, miktar olarak fazla ya da büyük porsiyonlar şeklinde tükettikleri belirtilmektedir (5). Amerika Tarım Bakanlığı'nın uyguladığı yerel anket çalışmaları
Tablo 4. Porsiyon seçimi ile ilişkili bazı parametrelerin korelasyon analizi

\begin{tabular}{lcc}
\hline Parametreler & $\mathbf{r}$ & $\mathbf{p}$ \\
\hline Yaş (yıl) & 0.095 & $* 0.032$ \\
Boy uzunluğu (cm) & 0.356 & $* * 0.000$ \\
Vücut ağırlığı (kg) & 0.177 & $* * 0.000$ \\
Beden kütle indeksi (kg/m²) & -0.015 & 0.742 \\
Annenin eğitim durumu & 0.015 & 0.727 \\
Annenin yaşı & 0.039 & 0.375 \\
Babanın eğitim durumu & -0.018 & 0.677 \\
Babanın yaşı & 0.030 & 0.504 \\
Ailenin aylık geliri (TL) & 0.003 & 0.947 \\
Uyku süresi (saat) & 0.059 & 0.186 \\
Kardeş sayısı & -0.030 & 0.502 \\
Enerji alımı (kkal/gün) & $* * 0.355$ & 0.000 \\
Karbonhidrat alımı (g/gün) & $* * 0.285$ & 0.000 \\
Protein alımı (g/gün) & $* * 0.308$ & 0.000 \\
Yağ alımı (g/gün) & $* * 0.297$ & 0.000 \\
\hline "Korelasyon gücü 0.05,"*Korelasyon gücü 0.001 & &
\end{tabular}

${ }^{*}$ Korelasyon gücü $0.05,{ }^{* *}$ Korelasyon gücü 0.001 
sonucunda, adölesanların porsiyon seçimlerinin, her geçen yll anlamlı bir şekilde arttığı gözlenmiştir (20). Bu nedenle bu çalışma adölesanların porsiyon seçimleri ve etkileyen etmenleri incelemek amacıyla yürütülmüştür.

Porsiyon büyüklüğü etkisinin cinsiyet ile ilişkisi deneysel ve gözlemsel çalışmalarla incelenmiştir. İngiltere'de cinsiyete göre porsiyon tüketimlerinin incelendiği bir çalışmada, geç adölesan dönemi olarak tanımlanan üniversite öğrencilerine 12 çeşit yiyecek sunulmuştur. Erkek öğrencilerin 6 çeşit yiyeceği, kızlara göre anlamlı olarak daha büyük porsiyonlarla tükettikleri gözlenmiştir (21). Huang ve arkadaşlarının (22), adölesan dönemdeki gençler üzerinde yürüttüğü bir diğer çalışmada, erkeklerin belirli besinleri, kızlara oranla daha büyük porsiyonlarda tükettikleri bildirilmiştir. San Diego Üniversitesi öğrencilerinde yapılan çalışmada ise belirli besinlerin porsiyon büyüklüklerinde, cinsiyete göre anlamlı bir fark olduğu gösterilmiştir (23). Çalışma grubumuzda cinsiyet ve porsiyon seçimi arasında anlamlı bir fark bulunmuş, erkek öğrencilerin kızlara göre daha büyük porsiyonları tercih ettikleri görülmüştür. Bu sonucun erkek ve kız öğrencilerin özellikle ergenlik döneminde enerji gereksinimlerindeki farklılıklara bağlı olabileceği düşünülmüştür.

Amerika'da Huang et al. (22) yaptığı çalışmada, çocukların vücut ağırlığı ve tüketilen porsiyonların büyüklükleri arasında pozitif bir korelasyon saptanmış, vücut ağırlığı fazla olan çocukların daha büyük porsiyonlar tükettikleri gözlenmiştir. Beden kütle indeksi ve porsiyon büyüklüğü arasındaki ilişki birçok çalışmanın konusu olmuştur. Burger et al. (23), Westerp et al. (24) ve McConahy et al. (25) yaptıkları çalışmalarda, BKİ ile porsiyon büyüklüğü arasında pozitif ilişki bulunurken, Brunstrom ve arkadaşlarının (21) yaptığı çalışmada, BKİ ile tüketilen porsiyonların büyüklüğü arasında herhangi bir ilişki bulunamamıştır. İngiltere'de Albar ve arkadaşlarının (7), yüksek enerjili yiyeceklerin porsiyon miktarları ile adölesanların BKİleri arasındaki ilişkiyi inceledikleri çalışmada, bisküvi, kahvaltılık gevrekler, kurabiye, pasta ve pastane ürünlerinin özellikle yüksek BKİye sahip adölesanlar tarafindan daha büyük porsiyonlarda tüketildiği görülmüştür. Çalışma grubumuzdaki adölesanların BKİleri ile porsiyon seçimleri arasında herhangi bir ilişki saptanmamıştır. $\mathrm{Bu}$ sonucun, porsiyonların öğrenciler tarafından tüketilmesi yerine hazırlanan görsellerden seçilmiş olmasından kaynaklanabileceği düşünülmüştür. Bir meta-analizde bu durum desteklenmiş, porsiyonların katılımcılar tarafından tüketilmesi porsiyonların seçilmesiyle kıyaslanmış ve porsiyon tüketiminin daha tutarlı sonuçlar gösterdiği ifade edilmiştir (26).

Porsiyon büyüklüğünün enerji alımını arttırdığı laboratuvar çalışmaları ile ispatlanmıştır. Smethers ve arkadaşları (8) çocuklara (3-6 yaş) ana öğünlerini 5 gün boyunca büyük porsiyonlarla servis etmiş, çocukların büyük porsiyonlarla günlük enerji alımlarını \%18 oranında arttırdıkları gözlenmiştir. Bir başka laboratuvar çalışmasında yetişkinlere 11 gün büyük porsiyon servis edilmiş, katılımcıların büyük porsiyonlarla günlük enerji alımlarını yaklaşık 450 kkal/gün arttırdıkları gözlenmiştir (27). Buna paralel olarak bu çalışmada öğrencilerin porsiyon seçimleri ile günlük enerji ve makro besin ögesi alımı incelenmiş, büyük porsiyonları seçen öğrencilerin günlük enerji ve makro besin ögesi alımlarının daha yüksek olduğu gözlenmiştir. Bu durumun öğrencilerin günlük hayatlarında da büyük porsiyonlar tercih etmelerinden kaynaklı olabileceği düşünülmüştür.

Yapılan çalışmalar bireylerin açlık durumuna bağlı olarak büyük porsiyonlardan tüketimini arttırmaya daha yatkın olduklarını göstermiştir. Adolesanlarda yapılan bir çalışmada katılımcıların açlık durumları ve porsiyon tüketimleri incelenmiş, açlık düzeyi arttıkça bireylerin daha büyük porsiyonlar tükettikleri belirtilmiştir (21). Buna paralel olarak, çalışma grubumuzda öğrencilere hem açlık hem tokluk durumunda porsiyon seçimleri sorulmuş ve öğrencilerin tokluk durumunda anlamlı ölçüde daha küçük porsiyonları seçtiği gözlenmiştir $(p<0.05)$. Bu durumun öğrencilerin porsiyon seçerken açlık ve tokluk düzeylerini göz önünde bulundurmalarına bağlı olabileceği düşünülmüştür.

$\mathrm{Bu}$ çalışmada bazı sinırlılıklar bulunmaktadır. Öğrencilerin tamamına öğlen yemeğinden hemen 
önceki saatlerde açlık durumunda porsiyon anketi ile öğlen yemeğinden sonraki ilk $45 \mathrm{dk}$ içerisinde de tokluk durumunda porsiyon anketi uygulanmıştır. Öğrencilerin porsiyon tüketimleri konusunda daha fazla bilgi edinmek adına tüm öğünleri incelenmeli ve ileri çalışmalar geliştirilmelidir.

Sonuç olarak, öğrencilerin porsiyon seçimlerinin günlük enerji ve makro besin ögesi alımına paralel olduğuancakbu seçimlerinbeden kütleindekslerinden bağımsız olduğu gözlenmiştir. Son yıllarda gerek evlerde, gerekse ev dışında porsiyonların büyüdüğü ve büyüyen porsiyonların obeziteye neden olduğu bildirilmektedir. Adölesan döneminde obezitenin önlenebilmesi için, adölesanların artan porsiyon büyüklüklerine karşılık, doğru porsiyon seçimleri konusunda bilinçlendirilmesinin yararlı olacağı düşünülmüştür.

Çıkar çatışması - Conflict of interest: Yazarlar çıkar çatışması olmadığını beyan ederler. - The authors declare that they have no conflict of interest.

\section{KAYNAKLAR}

1. Roe LS, Kling SM, Rolls BJ. What is eaten when all of the foods at a meal are served in large portions? Appetite 2016;99:1-9.

2. Steenhuis I, Poelman M. Portion size: latest developments and interventions. Curr Obes Rep. 2017;6(1):10-7.

3. Jelalian E, Steele G, editors. Handbook of Childhood and Adolescent Obesity. 1st ed. New York: Springer; 2008. $145 \mathrm{p}$.

4. World Health Organization. E-library of Evidence for Nutrition Actions (eLENA). WHO: Geneva, Switzerland. Available from: http://www.who.int/elena/en/ Accessed January 23, 2019.

5. Hetherington MM, Blundell-Birtill P. The portion size effect and overconsumption-towards downsizing solutions for children and adolescents. Nutr Bull. 2018;43(1):61-8.

6. Piernas C, Popkin BM. Increased portion sizes from energy-dense foods affect total energy intake at eating occasions in US children and adolescents: patterns and trends by age group and sociodemographic characteristics, 1977-2006. Am J Clin Nutr. 2011;94(5):1324-32.
7. Albar SA, Alwan NA, Evans CE, Cade JE. Is there an association between food portion size and BMI among British adolescents? Br J Nutr. 2014;112(5):841-51.

8. Smethers AD, Roe LS, Sanchez CE, Zuraikat FM, Keller KL, Kling SM, et al. Portion size has sustained effects over 5 days in preschool children: a randomized trial. Am J Clin Nutr. 2019;5:1361-1372.

9. Faul F, Erdfelder E, Buchner A, Lang AG. Statistical power analyses using $G^{*}$ Power 3.1: Tests for correlation and regression analyses. Behav Res Methods. 2009;41(4):1149-60.

10. Lohman TG, Roche AF, Martorell R. Anthropometric Standardization Reference Manual. 23th ed. Champaign, IL: Human Kinetics Books; 1988.151 p.

11. US Department of Health and Human Services; US Department of Agriculture. 2015-2020 Dietary Guidelines for Americans. 8th ed. Washington, DC: US Dept of Health and Human Services; December 2015. http://www.health.gov/DietaryGuidelines. Accessed January 22, 2019.

12. Lillegaard IT, Øverby NC, Andersen LF. Can children and adolescents use photographs of food to estimate portion sizes? Eur J Clin Nutr. 2005;59(4):611-7.

13. Türkiye Beslenme Rehberi (TÜBER) 2015, T.C. Sağllk Bakanlığı Yayın No:1031:978-975-590-608.

14. United States Department of Agriculture. Choosemyplate. gov Available from: http://www.choosemyplate.gov/. Accessed January 22, 2019.

15. World Health Organization (WHO), Growth reference data for 5-19 years, WHO Reference, 2007. Available at:http://www.who.int/growthref/en/ Accessed January 23, 2019.

16. Ogden CL, Flegal KM. Changes in terminology for childhood overweight and obesity. Natl Health Stat Report. 2010;(25):1-5.

17. Beslenme Bilgi Sistemi (BEBİS) 4. versiyon, İstanbul, 2004. Veri bankaları: Bundeslebensmittelschlüssel (BLS) 2.3 ve USDA12. www.bebis-tr.com Accessed January 24, 2019.

18. Gibson RS. Principles of Nutritional Assessment. 2nd ed. USA: Oxford University Press; 2005. 218 p.

19. Story M, Stang J. Nutrition needs of adolescents. Guidelines for adolescent nutrition services, Minneapolis, MN:Centre for Leadership, Education and Training in Maternal and Child Nutrition Division of Epidemiology and Community Health, School of Public Health: University of Minnesota; 2005. 21-34 p.

20. US Department of Agriculture, Beltsville Human Nutrition Research Center, US Department of Health and Human Services. What we eat in America, NHANES 2010. Available from: http://www.cdc.gov/nchs/about/ major/nhanes/nhanes2005-2006/dr1tot_c.xpt. Accessed January 22, 2019. 
21. Brunstrom JM, Rogers PJ, Pothos EM, Calitri R, Tapper K. Estimating everyday portion size using a method of constant stimuli: In a student sample, portion size is predicted by gender, dietary behaviour, and hunger, but not BMI. Appetite. 2008;51(2):296-301.

22. Huang TTK, Howarth NC, Lin BH, Roberts SB, McCrory MA. Energy intake and meal portions: associations with BMI percentile in US children. Obes Res. 2004;12(11):1875-85.

23. Burger KS, Kern M, Coleman KJ. Characteristics of selfselected portion size in young adults. J Am Diet Assoc. 2007;107:611-8.

24. Westerterp-Plantenga MS, Pasman WJ, Yedema MJW,
Wijckmans-Duijsens NEG. Energy intake adaptation of food intake to extreme energy densities of food by obese and non-obese women. Eur J Clin Nutr. 1996;50:401-7.

25. McConahy KL, Smiciklas-Wright H, Birch LL, Picciano MF. Food portions are positively related to energy intake and body weight in early childhood. J Pediatr. 2002;140:340-7.

26. Zlatevska N, Dubelaar C, Holden SS. Sizing up the effect of portion size on consumption: a meta-analytic review. Journal of Marketing. 2014;78(3):140-54.

27. Rolls BJ, Roe LS, Meengs JS. The effect of large portion sizes on energy intake is sustained for 11 days. Obesity 2007;15(6):1535-43. 